\title{
Morphological variables restrict flower choice of Lycaenid butterfly species: implication for pollination and conservation
}

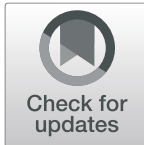

\author{
Subha Shankar Mukherjee ${ }^{1,2}$ and Asif Hossain ${ }^{2^{*}}$ (D)
}

\begin{abstract}
Background: Butterflies make an important part for plant-pollinator guild. These are nectar feeder or occasionally pollen feeder and thus proboscis of the butterfly species are considered as one of the most important variable in relation to the collection of food from plants. In butterfly-plant association, nectar source is principally determined by quality of nectar, corolla length, and nectar quantity. For the butterfly, nectar uptake is determined by proboscis length because flowers with long corolla restrict butterfly species containing shorter proboscis. Empirical studies proved that butterfly species with high wing loading visit clustered flowers and species with low wing loading confined their visit to solitary or less nectar rich flowers. The present study tries to investigate the flower preference of butterfly species from Lycaenidae family having very short proboscis, lower body length, lower body weight and wing span than the most species belonging from Nymphalidae, Pieridae, Papilionidae, and Hesperiidae.

Results: Butterflies with shorter proboscis cannot access nectar from deeper flower. Although they mainly visit on less deeper flower to sucking nectar, butterflies with high wing loading visits clustered flowers to fulfill their energy requirements. In this study, we demonstrated flower choice of seven butterfly species belonging to Lycanidiae family. The proboscis length maintains a positive relationship with body length and body weight. Body length maintains a positive relationship with body weight and wing span. Wing span indicate a strong positive relationship with body weight. This study proved that these seven butterfly species namely Castalius rosimon (CRN), Taracus nara (TNA), Zizinia otis (ZOT), Zizula hylax (ZHY), Jamides celeno (JCE), Chilades laius (CLA), and Psuedozizeeria maha (PMA) visit frequently in Tridax procumbens (TPR), Ocimum americanum (OAM) and Syndrella nodiflora (SNO). The species do not visit Lantana camara (LCA) and Catharanthus roseus (CRO) plants.

Conclusion: The present study proved that butterfly species visits frequently in Tridax procumbens (TPR), Ocimum americanum (OAM) but less frequently in Syndrella nodiflora (SNO). So, that study determined the butterfly species helps in pollination of these herbs that in turn helps the conservation of these butterfly species.
\end{abstract}

Keywords: Morphological variables, Butterflies, Conservation, Pollination

\section{Introduction}

For reproductive success of arthropod pollinators, evolution of angiosperm flowering plants are closely linked (Barth 1991). Different traits of the flowering plants such as colour, scents are largely decide pollinator insect guild (Dobson

\footnotetext{
* Correspondence: asifhossain.bu@gmail.com

${ }^{2}$ Department of Zoology, The University of Burdwan, Golapbag, Burdwan 713104, India

Full list of author information is available at the end of the article
}

1994; Lunau and Maier 1995). Pollinators utilize plant signals to differentiate between morphologically similar plants such as honey bees and bumblebees do for nectar collection (Kunze and Gumbert 2001). It has been described that there is good match between flowers and feeding structures of insects (Heinrich 1976; Grant and Grant 1983; Johnson and Steiner 1997; Alexandersson and Johnson 2002; Temeles and Kress 2003). In plant-pollinator guild, butterfly make important part; mainly they feed on nectar or pollen and thus the

(c) The Author(s). 2021 Open Access This article is licensed under a Creative Commons Attribution 4.0 International License, which permits use, sharing, adaptation, distribution and reproduction in any medium or format, as long as you give appropriate credit to the original author(s) and the source, provide a link to the Creative Commons licence, and indicate if changes were made. The images or other third party material in this article are included in the article's Creative Commons licence, unless indicated otherwise in a credit line to the material. If material is not included in the article's Creative Commons licence and your intended use is not permitted by statutory regulation or exceeds the permitted use, you will need to obtain permission directly from the copyright holder. To view a copy of this licence, visit http://creativecommons.org/licenses/by/4.0/. 
proboscis of the visitor butterfly species are considered as one of the important variable (Krenn et al. 2005). During feeding, these lepidopteran insects contribute pollination in many of the visiting plants (Lewis 1989; Goulson et al. 1997; Weiss and Papaj 2003). Often, these insects are known as opportunistic feeder of the flowering plants (Courtney 1986). Which flowers will be preferred by the visitor species and which not depends on the colour of the flower also (Ilse 1928). Many studies proved that several species from Papillinodiae and Pieridae family preferred purple colours and yellow colour is preferable for some species from Pieridae and Nymphalidae family (Ilse and Vaidya 1956; Swihart 1970; Scherer and Kolb 1987; Tiple et al. 2006). In butterfly-plant association, for the butterflies, attraction to the nectar source is dependent on quality of nectar, corolla length, and nectar quantity (Corbet 2000). In case of butterfly, nectar uptake is determined by proboscis length. Therefore flowers with long corolla restrict butterfly species with shorter proboscis to nectar uptake (Corbet 2000). Empirical studies describe that in case of butterfly species those with high wing loading visits clustered flowers and species with low wing loading restricts their visits to solitary flowers (Corbet 2000). Butterflies with larger bodies require rich food source to fulfil their energy requirements (Tiple 2009). In this study, we try to investigate flowers preference of seven species from Lycaenidae family because these species contain very short proboscis, lower body length, lower body weight and wing span than the most species belonging from Nymphalidae, Pieridae, Papilionidae, and Hesperiidae (Tiple 2009; Mukherjee and Hossain 2020). The aim of the present study is to determine how morphological variables of these Lycaenid butterfly species correlate with flower selection, which plants are preferable by the butterfly species and how these flowering plants plays a role to conserve these species and how butterfly species helps in pollination of these plants by measuring frequency of visits of the butterfly species because higher the frequency of visits positively related to higher the chances of pollination because during collection of food the pollen grains are attached to the insect body parts (Son et al. 2019).

\section{Materials and methods}

Study area and species sampling

The study was conducted in and around Leprosy mission campus (23⒈ $46^{\prime \prime} \mathrm{N} 86^{\circ} 20^{\prime} 15^{\prime \prime}$ E) during the monsoon season (July to September) of 2019 and 2020 between 8 AM to $12 \mathrm{PM}$. The study site contains several plant species including Lantana camara (LCA), Catharanthus roseus (CRO), Tridax procumbens (TPR), Ocimum americanum (OAM) and Syndrella nodiflora (SNO). The butterfly species belonging from Lycaenidae family were observed not to visit in LCA and CRO. These species visit only in TPR, OAM and SNO. The frequencies of visit by these species were recorded in the plants only when butterflies uncoiled their proboscis for collecting food. Individuals of specimen from each species were collected by using insect net for the purpose of measurement of morphological variables.

\section{Measurement of morphological variables}

Proboscis length (PL) of the butterfly species were measured by inserting a needle in the coiled proboscis and length of the proboscis was determined by the distance from the labial palps to the tip of the proboscis by the use of electronic digital Vernier calliper (Thermocare) (Kunte 2007). The distance between two wing tips considered as the length of the wing span (WS). The body length (BL) was determined from the area between eyes to the tip of the abdomen (Van Dyck 1997). For determination of body weight (BW) first the butterfly species immobilized in a refrigerator for $30 \mathrm{~min}$ (Duster 2018),

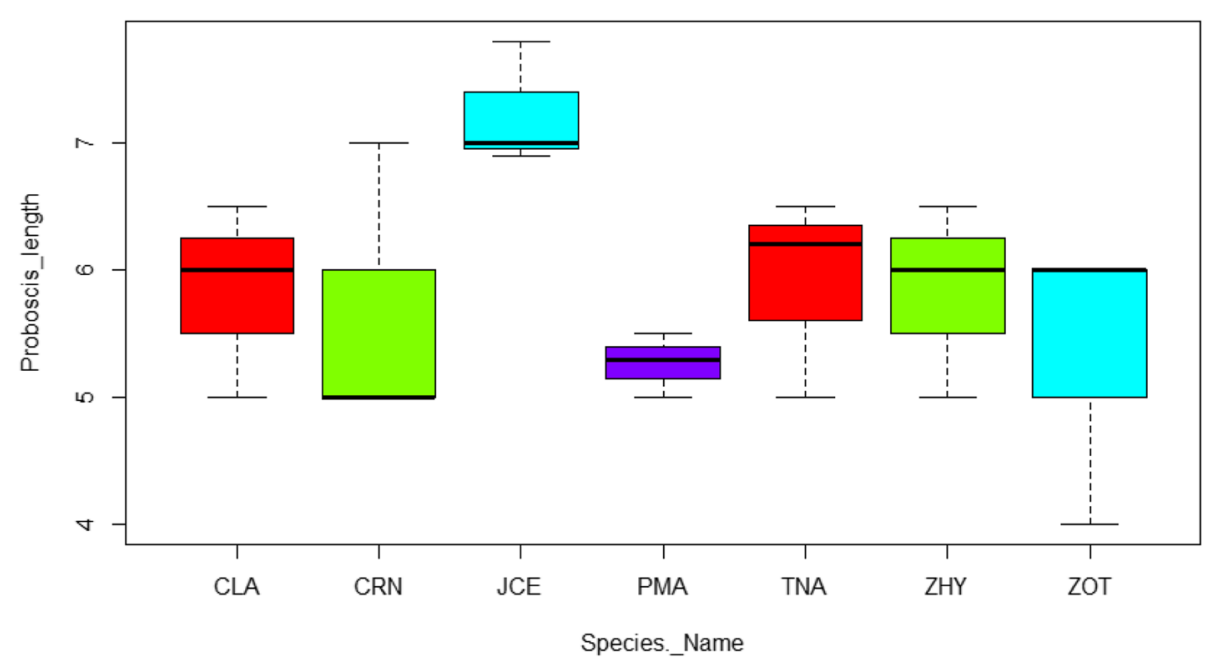

Fig. 1 Box plot representing proboscis length of seven butterfly species. In which JCE has highest proboscis length 


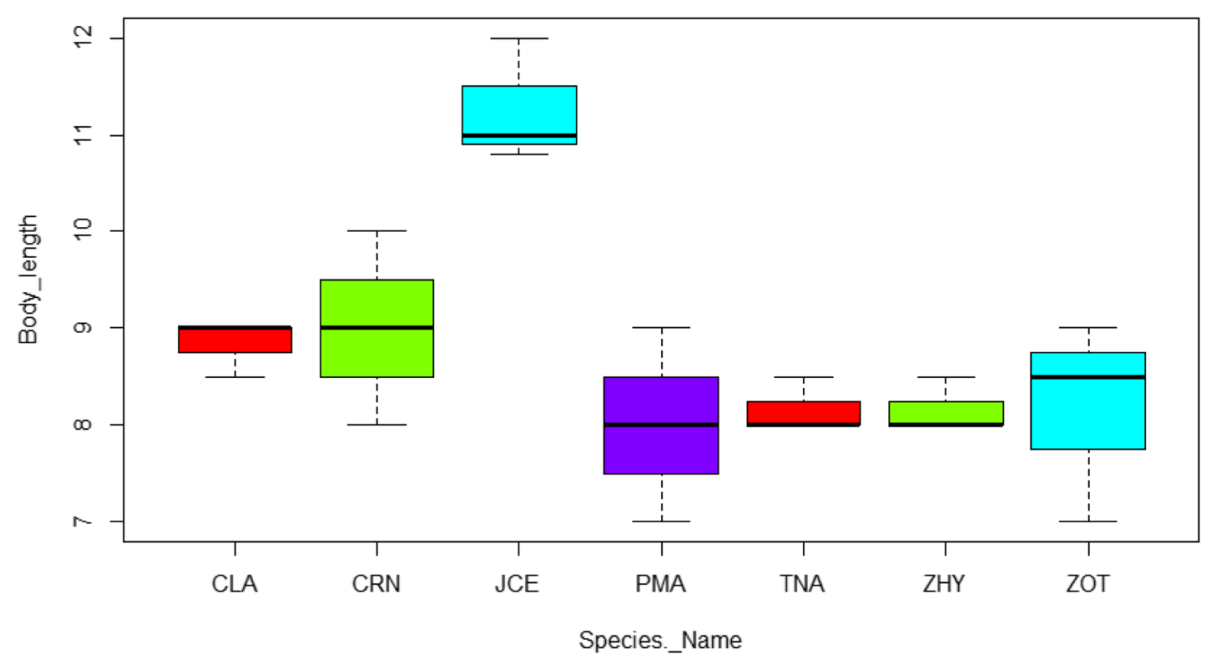

Fig. 2 Box plot representing body length of seven butterfly species. In which JCE has highest body length

then fresh weight was taken in a digital electronic balance machine. After that butterflies were acclimatized for $1 \mathrm{~h}$ to regain flight ability and then they were release without noticeable harm (Mukherjee and Hossain 2020).

\section{Floral biology}

Among plant species present in the study area Lantana camara (LCA) is a large shrub belonging to family Verbenaceae with $15 \mathrm{~mm}$ corolla tube, Catharanthus roseus (CRO) belonging to family Apocynaceae is a perennial small herb or sub shrub with pink or white flowers. Ocimum americanum (OAM) belongs to family Lamiaceae is an annual herb with white or lavender flowers, Tridax procumbens (TPR) belongs to family Asteraceae is an annual herb with $8 \mathrm{~mm}$ corolla tube and Syndrella nodiflora (SNO) belongs to family
Asteraceae with yellow flowers. The corolla of all flowers are tubular in shape.

\section{Statistical analyses}

To determine whether there is significant difference between morphological variables of the butterfly species (groups) one way Multivariate analysis of variance (MANOVA) was performed. Pearson's correlation analysis and Principal component analysis (PCA) were performed to interpret the relationship between morphological variables of visitor butterfly species. To interpret whether significant difference were present for three plants in terms of frequency of visit of the butterfly species and the data set does not follow normal distribution that is why Kruskal-Wallis test followed by post hoc Dunn's test was performed. Pearson's correlation analysis and Kruskal-Wallis test was performed by R-studio 3.6.3 ( $\mathrm{R}$

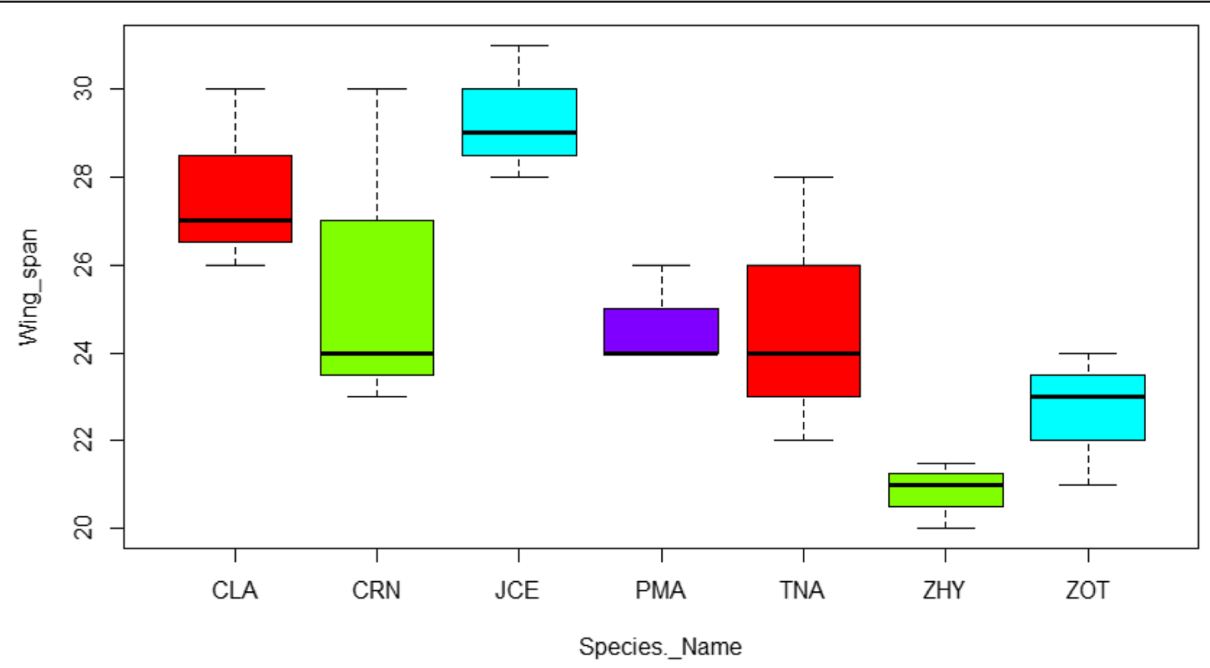

Fig. 3 Box plot representing wing span of seven butterfly species. In which JCE has highest wing span 


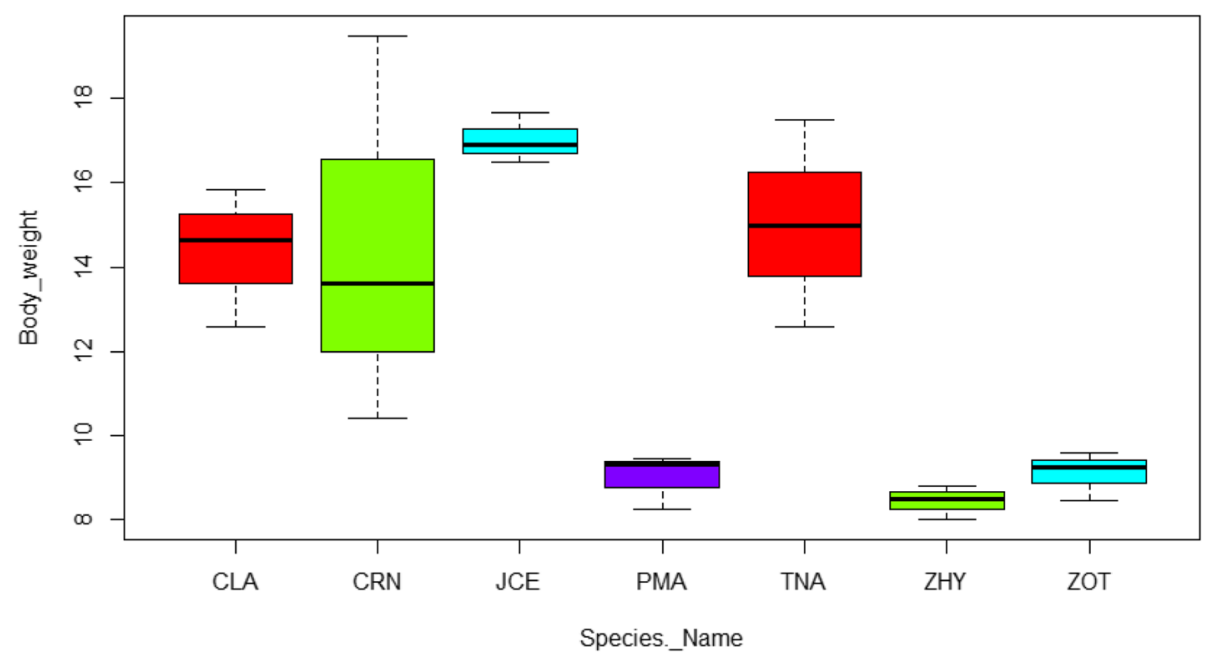

Fig. 4 Box plot representing body weight of seven butterfly species. In which JCE has highest body weight

studio team 2020) and one way Multivariate analysis of variance (MANOVA), Principal component analysis (PCA), cluster analysis were performed by PAST 4.06 (Hammer et al. 2001).

\section{Results}

The butterfly species namely Castalius rosimon (CRN), Taracus nara (TNA), Zizinia otis (ZOT), Zizula hylax (ZHY), Jamides celeno (JCE), Chilades laius (CLA) and Psuedozizeeria maha (PMA) visited in Ocimum americanum (OAM), Tridax procumbens (TPR) and Syndrella nodiflora (SNO). All the butterfly species visited Tridax procumbens (TPR) but in case of Ocimum americanum (OAM) and Syndrella nodiflora (SNO) only three and two butterfly visit respectively. Castalius rosimon (CRN), Zizinia otis (ZOT) and Taracus nara (TNA) found to be visit in Ocimum americanum (OAM). Psuedozizeeria maha (PMA) and Zizula hylax (ZHY) visited Syndrella nodiflora (SNO). The results of one way MANOVA shows that there is significant difference found in morphological variables of the visitor butterfly species (Wilk's lamda $=0.0238, \mathrm{df} 1=24, \mathrm{df} 2=39.58 F=3.16, p$ $<0.001)$. The proboscis length was highest for Jamides celeno (JCE) (7.23 \pm 0.28$)$ and lowest for Psuedozizeeria maha (PMA) (5.26 \pm 0.14) (Fig. 1). Body length was highest for Jamides celeno (JCE) (11.26 \pm 0.37$)$ and lowest for Psuedozizeeria maha (PMA) $(8 \pm 0.57)$ (Fig. 2). Body weight was highest for Jamides celeno (JCE) (17.01 $\pm 0.33)$ and lowest for Zizula hylax (ZHY) $(8.43 \pm 0.23)$ (Fig. 3). Wing span was highest for Jamides celeno (JCE) $(29.33 \pm 0.88)$ and lowest for Zizula hylax (ZHY) (20.83 \pm 0.44 ) (Fig. 4). Proboscis length maintain a strong relationship between body length $(r=0.74, p<0.05)$ and body weight $(r=0.62, p<0.05)$ but not with wing span $(r=0.21, p>0.05)$. Body length maintain a strong positive relationship with wing span $(r=0.59, p<0.05)$ and body weight $(r=0.68, p<0.05)$. Wing span maintain a strong relationship with body weight $(r=0.53, p<$ $0.05)$. PCA results show that the first two principal components have 67.82 and 19.938 percent variance with 2.71 and 0.79 Eigen values respectively (Table 1). The Pearson's correlation plot and PCA biplot show body length, body weight and proboscis length maintain a strong positive correlation but wing span maintain weak relation with proboscis length (Figs. 5 and 6.).

The classical clustering based on algorithm UPGMA for frequency of butterfly visits in three plants (groups) by using Euclidian distance and presence- absence records in the three plants by using Jaccard index. The classical cluster analysis based on Euclidian distance proved that Syndrella nodiflora (SNO) and Ocimum americanum (OAM) are quite similar but Tridax procumbens (TPR) is dissimilar from both those groups in terms of frequency of visits of butterflies in those plants (Fig. 7). In case of presence-absence records wherein the apparent presence or absence of each butterfly species are recorded in the three plants namely Tridax procumbens (TPR) and Ocimum americanum (OAM) and Syndrella nodiflora (SNO) showed that Tridax procumbens (TPR) and Ocimum americanum (OAM) are related but

Table 1 Results of PCA analysis between morphological variables of seven butterfly species showing PC1 and PC2 has highest eigenvalues and percent variance

\begin{tabular}{lll}
\hline PC & Eigenvalue & \% variance \\
\hline 1 & 2.71281 & 67.82 \\
2 & 0.797521 & 19.938 \\
3 & 0.349533 & 8.7383 \\
4 & 0.140134 & 3.5033 \\
\hline
\end{tabular}




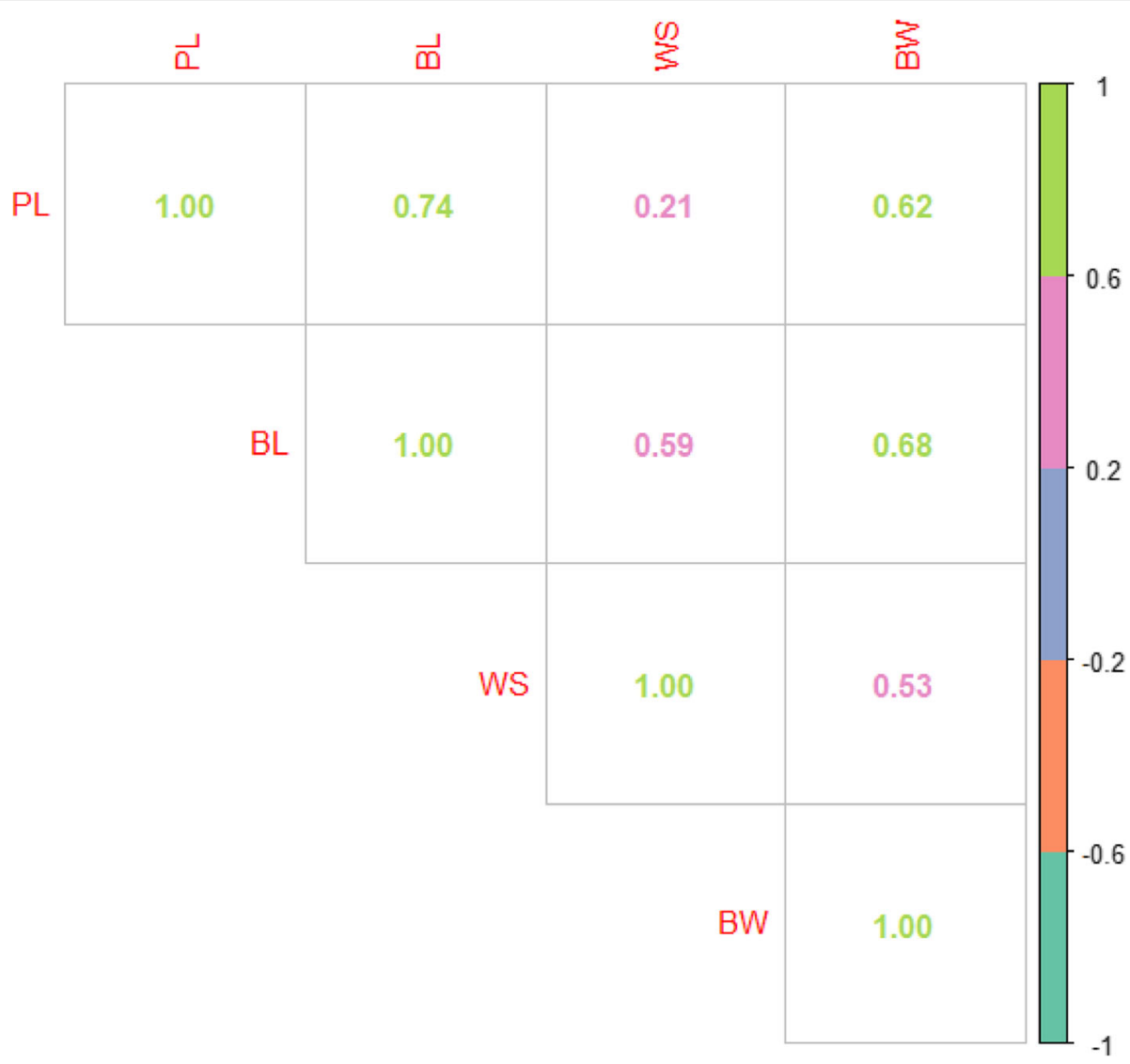

Fig. 5 Correlation plot of four morphological variables namely proboscis length, body length, wing span and body weight of seven butterfly species. ( $\mathrm{PL}=$ Proboscis length, $\mathrm{BL}=$ body length, $\mathrm{WS}=$ wing span, $\mathrm{BW}=$ body weight)

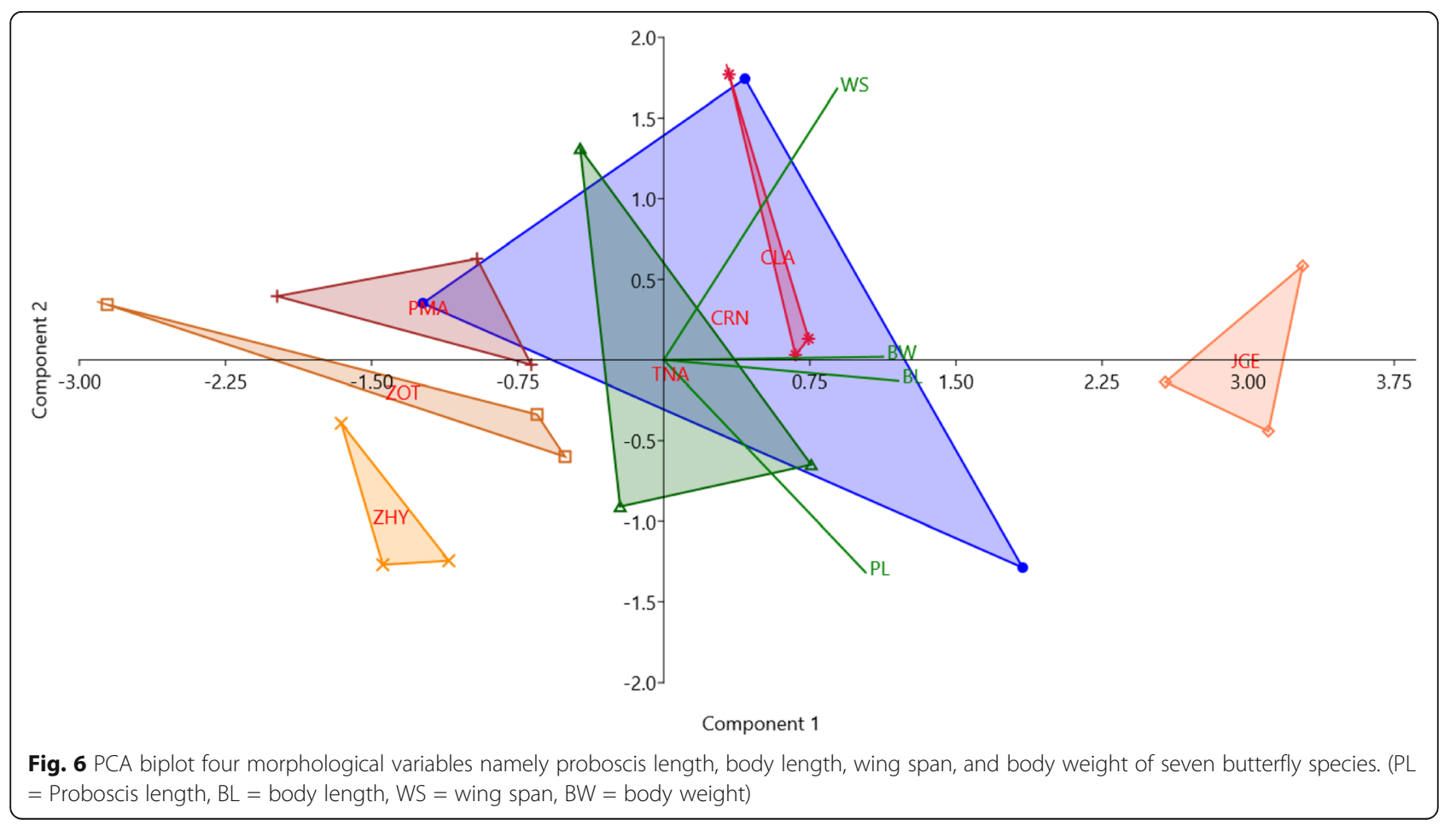




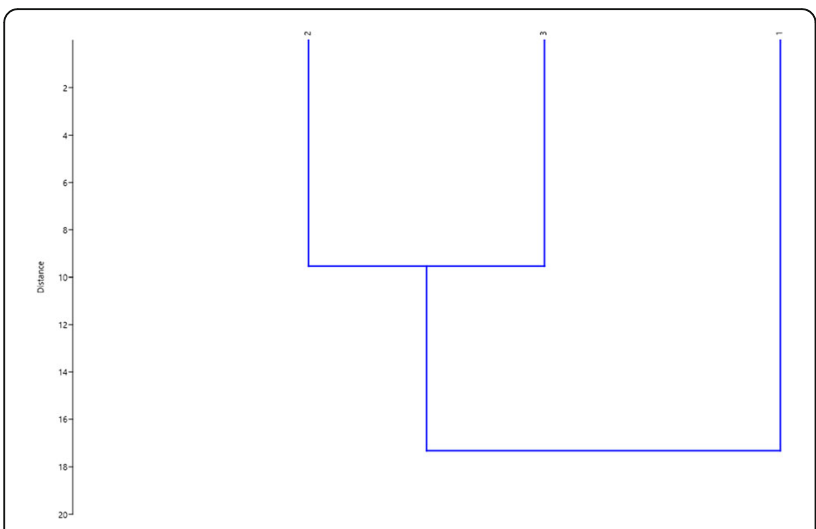

Fig. 7 Dendogram of three plants based on frequency of visits of butterflies by using Euclidian distance. (1, 2, and 3 indicating Tridax procumbens, Ocimum americanum, and Syndrella nodiflora.)

Syndrella nodiflora (SNO) is dissimilar from both these groups (Fig. 8). Kruskal-Wallis test proved that the three plants are different from each other in term of frequency of visit ( Kruskal-Wallis chi-squared $=10.969, \mathrm{df}=2, p$ $<0.05$ ) and the result of post hoc Dunn's test revealed that there was no significant difference was found between Syndrella nodiflora (SNO) and Ocimum americanum (OAM) $(p>0.05)$ but significant difference was found between Ocimum americanum (OAM)-Tridax procumbens (TPR) $(p<0.05)$ and Tridax procumbens (TPR)-Syndrella nodiflora (SNO) $(p<0.05)$ (Table 2). In terms of frequency of visit by the butterfly species Tridax procumbens (TPR) has highest visit followed by Ocimum americanum (OAM) and Syndrella nodiflora (SNO) (Fig. 9).

\section{Discussion}

The results shows that the seven butterfly species from Lycaenidae family visit Tridax procumbens (TPR) and

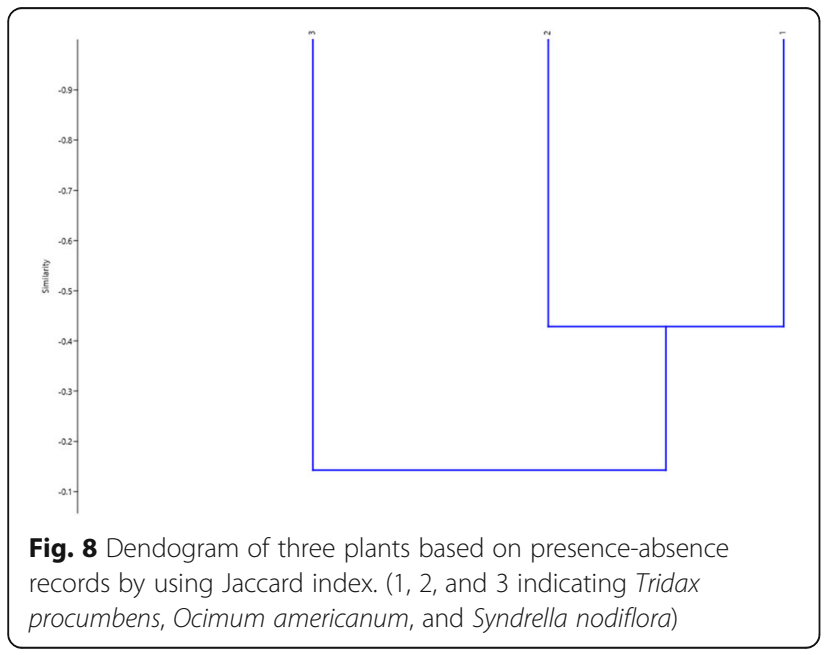

Ocimum americanum (OAM) frequently rather than Syndrella nodiflora (SNO). It was also found that all the species visit Tridax procumbens (TPR), three species visit Ocimum americanum (OAM) and two species visit Syndrella nodiflora (SNO), but no butterfly visit in Lantana camara (LCA) and Catharanthus roseus (CRO) which corolla length is $15 \mathrm{~mm}$ and $21 \mathrm{~mm}$ (measured during field survey) respectively. Tridax procumbens (TPR) has the highest visit rate followed by Ocimum americanum (OAM) and Syndrella nodiflora (SNO) respectively. So, the visitor butterfly species do not visit in these two plants because the corolla length of the flowers exceeds the proboscis length of the butterfly species (Corbet 2000; Tiple 2009). The reason of less frequently visit of butterfly species on Syndrella nodiflora (SNO) may be less food source in that flowers.

In case of nectar robbers with longer proboscis gain more energy (Kunte 2007) because species that contain longer proboscis access nectar from deeper flowers (May 1992), but the butterfly species with shorter proboscis cannot access nectar from the deeper flowers and they solely depends on the flowers having shorter or equal length of the proboscis length of the butterfly species. It is also observed that butterfly species with high wing load capacity visit clustered flowers but the species with low wing load capacity visit solitary, less nectar rich flowers (Corbet 2000). Heavier butterfly species require larger wings for flight (Dennis 1993) and thus require richer and abundant food to fulfil their energy requirements so they restrict their visit in clustered flowers that are rich in nectar (Tiple 2009). But in case of butterfly species with lower body weight with shorter wing load capacity and shorter proboscis visit solitary and flowers with shorter corolla tube because this enable them to collect food from these particular type of flowers and fulfil their energy requirements. During feeding on flowers butterfly also contribute the pollination of the plants (Lewis 1989; Goulson et al. 1997; Weiss and Papaj 2003). The present study aims to identify flowering plants those are preferred by the Lycaenidae family and comments in their potential role in pollination, thereby conservation of the host plant species and in alteration of conservation of butterfly species with shorter proboscis, wing span, body length, and lower body weight in the wild (Biswas et al. 2019; Mukherjee et al. 2021).

Table 2 Results of post hoc Dunn's test. $Z$ values are marked bold at $p<0.05$ level of significance

\begin{tabular}{llll}
\hline Comparison & $\boldsymbol{Z}$ & $\boldsymbol{P}$.unadj & P.adj \\
\hline OAM-SNO & 0.5390333 & 0.589863876 & 1.000000000 \\
OAM-TPR & $\mathbf{- 2 . 5 6 0 4 0 8 2}$ & 0.010454929 & 0.031364786 \\
SNO-TPR & $\mathbf{- 3 . 0 9 9 4 4 1 5}$ & 0.001938859 & 0.005816576 \\
\hline
\end{tabular}




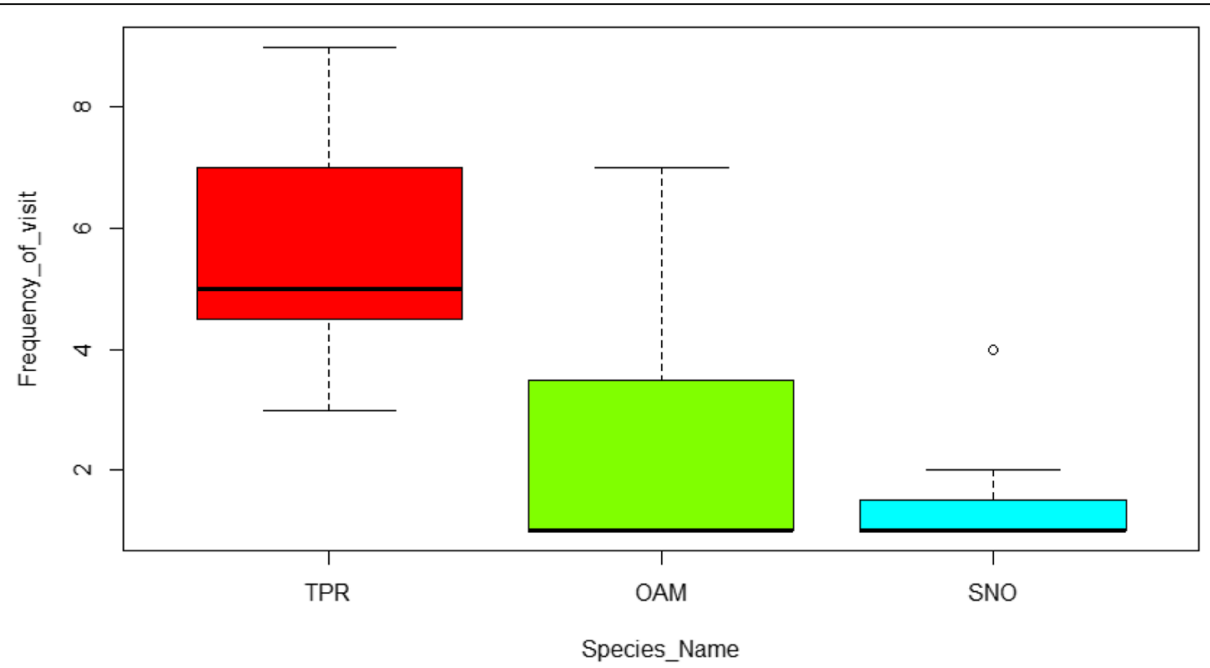

Fig. 9 Box plot representing frequency of visit by butterfly species in three plants. TPR has the highest frequency of visit

\section{Conclusion}

Nectarine events of seven species of butterfly species from Lycaenidae family were recorded in three flowers namely Tridax procumbens (TPR), Ocimum americanum (OAM) and Syndrella nodiflora (SNO) for 12 weeks in the study site. The survey was based on how morphological variables of the butterfly species from the Lycaenidae family restrict the flower selection. Pearson correlation analysis proved that proboscis length maintain a strong relationship between body length $(r=0.74$, $p<0.05)$ and body weight $(r=0.62, p<0.05)$ but not with wing span $(r=0.21, p>0.05)$. Body length maintain a strong positive relationship with wing span $(r=$ $0.59, p<0.05)$ and body weight $(r=0.68, p<0.05)$. Wing span maintain a strong relationship with body weight $(r=0.53, p<0.05)$. The study proved that frequency of visit by the butterfly species highest in Tridax procumbens (TPR) followed by Ocimum americanum (OAM) Syndrella nodiflora (SNO) respectively. So, the study determined the butterfly species helps in pollination of these herbs that in turn helps the conservation of these butterfly species.

\section{Abbreviations}

CLA: Chilades laius; CRN: Castalius rosimon; CRO: Catharanthus roseus; JCE: Jamides celeno; LCA: Lantana camara; MANOVA: Multivariate analysis of variance; OAM: Ocimum americanum; PCA: Principal component analysis; PMA: Psuedozizeeria maha; SNO: Syndrella nodiflora; TNA: Taracus nara; TPR: Tridax procumbens; ZHY: Zizula hylax; ZOT: Zizinia otis

\section{Acknowledgements}

The authors thankfully acknowledge Head, Department of Zoology, SKB University, Purulia, India, and Head, Department of Zoology, The University of Burdwan, Golapbag, Burdwan, India, for the facilities provided. The authors thankfully acknowledge the critical comments of the anonymous Reviewers and the suggestions of the respected Editor that helped in transforming the manuscript in the present form.
Authors' contributions

SSM collected the field data, and analyzed and interpreted the data. AH was a major contributor in setting the experimental design and writing the manuscript. All authors read and approved the final manuscript.

\section{Funding}

SSM acknowledges financial assistance to UGC, Government of India, in the form of JRF [Ref. No. 657/(CSIR-UGC NET June 2018)].

\section{Availability of data and materials}

The datasets during and/or analyzed during the current study available from the corresponding author on reasonable request.

\section{Declarations}

Ethics approval and consent to participate

No animal was harmed during the study although consent of university animal ethical committee was taken prior the study starts.

\section{Consent for publication}

Not applicable

\section{Competing interests}

The authors declare that they have no competing interests.

\section{Author details}

${ }^{1}$ Department of Zoology, SKB University, Purulia 723104, India. ${ }^{2}$ Department of Zoology, The University of Burdwan, Golapbag, Burdwan 713104, India.

Received: 30 October 2021 Accepted: 19 November 2021

Published online: 09 December 2021

\section{References}

Alexandersson $\mathrm{R}$, Johnson S. Pollinator-mediated selection on flower-tube length in a hawkmoth-pollinated Gladiolus (Iridaceae). Proc R Soc B. 2002;269(1491): 631-6. https://doi.org/10.1098/rspb.2001.1928.

Barth FG. Insects and flowers. In: The biology of a partnership. Princeton (NJ): Princeton University Press; 1991.

Biswas, S.J.B, Patra, D, Roy, S, Giri, S.K, Paul, S, Hossain, A. Butterfly diversity throughout Midnapore urban area in West Bengal, India J Threatened Taxa2019; 11(4): 14816-14826.https://doi.org/10.11609/jott.4587.11.14.1481 6-14826

Corbet SA. Butterfly nectaring flowers: butterfly morphology and flower form. Entomologia Experimentalis et Applicata. 2000;96:289-98. https://doi.org/10.1 046/j.1570-7458.2000.00708.x. 
Courtney SP. The ecology of pierid butterflies: dynamics and interactions. Adv Ecol Res. 1986;15:51-116. https://doi.org/10.1016/S0065-2504(08)60120-8.

Dennis RLH. Butterflies and climate change. Manchester (UK): Manchester University Press; 1993.

Dobson H. Floral volatiles in insect biology. In: Bernays E, editor. Insect-plant interactions, vol. 5. Boca Raton (FL): CRC Press; 1994. p. 47-81.

Düster JV, Gruber MH, Karolyi F, Plant JD, Krenn HW. Drinking with a very long proboscis: Functional morphology of orchid bee mouthparts (Euglossini, Apidae, Hymenoptera). Arthropod Struct Dev. 2018;47:25-35. https://doi. org/10.1016/j.asd.2017.12.004.

Goulson D, Ollerton J, Sluman C. Foraging strategies in the small skipper butterfly, Thymelicus flavus: when to switch? Anim Behav. 1997;53(5):100916. https://doi.org/10.1006/anbe.1996.0390.

Grant V, Grant KA. Hawkmoth pollination of Mirabilis longiflora (Nyctaginaceae). Proc Natl Acad Sci USA. 1983;80(5):1298-9. https://doi.org/10.1073/pnas.80. 5.1298

Hammer $\varnothing$, Harper DAT, Ryan PD. PAST: paleontological statistics software package for education and data analysis. Palaeontol Electron. 2001;4(1):9.

Heinrich B. Resource partitioning among some eusocial insects: bumblebees. Ecology. 1976;57(5):874-89. https://doi.org/10.2307/1941054.

Ilse D. U“ ber den farbensinn der tagfalter. Z Verl Physiol. 1928;8:658-92. https:// doi.org/10.1007/978-3-662-40182-8_1.

Ilse D, Vaidya V. G.. Spontaneous feeding response to colours in Papiliodemoleus L. Proceedings of the National Academy of Sciences. India Sect B. 1956;43(1): 23-31. https://doi.org/10.1007/BF03050215.

Johnson SD, Steiner KE. Long-tongued fly pollination and evolution of floral spur length in the Disadraconis complex (Orchidaceae). Evolution. 1997;51:45-53. https://doi.org/10.1111/j.1558-5646.1997.tb02387.x.

Krenn HW, Plant JD, Szucsich NU. Mouthparts of flower-visiting insects. Arthropod Struct Dev. 2005;34(1):1-40. https://doi.org/10.1016/j.asd.2004.10. 002.

Kunte K. Allometry and functional constraints on proboscis lengths in butterflies. Funct Ecol. 2007;21(5):982-7. https://doi.org/10.1111/j.1365-2435.2007.01299.x.

Kunze J, Gumbert A. The combined effect of color and odor on flower choice behavior. of bumble bees in flower mimicry systems. Behav Ecol. 2001;12(4): 447-56. https://doi.org/10.1093/beheco/12.4.447.

Lewis AC. Flower visit consistency in Pieris rapae, the cabbage butterfly. J Anim Ecol. 1989;58(1):1-13. https://doi.org/10.2307/4982.

Lunau K, Maier, E.J. Innate colour preferences of flower visitors. J Comp Physiol A 1995 177:1-19. https://doi.org/10.1007/BF00243394, 1.

May PG. Flower selection and the dynamics of lipid reserves in two nectarivorous butterflies. Ecology. 1992;73(6):2181-91. https://doi.org/10.2307/1941466.

Mukherjee SS, Ahmed MT, Hossain A. Role of a Global Invasive Species (GIS), Lantana camara in conservation and sustenance of local butterfly community. Acta Ecol Sin. 2021. https://doi.org/10.1016/j.chnaes.2021.02.008.

Mukherjee SS, Hossain A. Role of morphological variables of the visitor butterfly species in relation to their foraging behaviour on Lantana camara: Implication for conservation. Acta Ecol Sin. 2020. https://doi.org/10.1016/j. chnaes.2020.11.003.

RStudio Team. RStudio: Integrated Development for R. RStudio. Boston, MA: PBC; 2020. http://www.rstudio.com/. Accessed 16 Aug 2021.

Scherer C, Kolb G. The influence of color stimuli on visually controlled behavior in Aglaisurticae L. and Parargeaegeria L. (Lepidoptera). J Comp Physiol A. 1987;61:891-8. https://doi.org/10.1007/BF00610230.

Son HD, Im HT, Choi SW. Pollination of Cleisostomascolopendrifolium (Orchidaceae) by megachilid bees and determinants of fruit set in southern South Korea. J Ecol Environ. 2019;43:3. https://doi.org/10.1186/s41610-018-01 02-3.

Swihart SL. The neural basis of colour vision in the butterfly Papiliotroilus. J Insect Physiol. 1970;16(8):1623-36. https://doi.org/10.1016/0022-1910(70)90262-3.

Temeles EJ, Kress WJ. Adaptation in a plant-hummingbird association. Science. 2003;300(5619):630-3. https://doi.org/10.1126/science.1080003.

Tiple AD, Deshmukh VP, Dennis RLH. Factors influencing nectar plant resource visits by butterflies on a university campus: implications for conservation. Nota Lepidopterologica. 2006;28:213-24.

Tiple AD, Khurad AM, Dennis RLH. Adult butterfly feeding-nectar flower associations: Constraints of taxonomic affiliation, butterfly, and nectar flower morphology. J Nat Hist. 2009;43(13-14):855-84. https://doi.org/10.1080/00222 930802610568

Van Dyck H, Matthysen E, Dhondt A. A. Mate-locating strategies are related to relative body length and wing colour in the speckled wood butterfly
Parargeaegeria. Ecol Entomol. 1997;22(1):116-20. https://doi.org/10.1046/j.13 65-2311.1997.00041.x

Weiss MR, Papaj DR. Colour learning in two behavioural contexts: how much can a butterfly keep in mind? Anim Behav. 2003;65(3):425-34. https://doi.org/10.1 006/anbe.2003.2084.

\section{Publisher's Note}

Springer Nature remains neutral with regard to jurisdictional claims in published maps and institutional affiliations.
Ready to submit your research? Choose BMC and benefit from:

- fast, convenient online submission

- thorough peer review by experienced researchers in your field

- rapid publication on acceptance

- support for research data, including large and complex data types

- gold Open Access which fosters wider collaboration and increased citations

- maximum visibility for your research: over $100 \mathrm{M}$ website views per year

At BMC, research is always in progress.

Learn more biomedcentral.com/submissions 